\title{
Symbols in Mari Wedding Songs
}

\author{
Lyubov A. Abukaeva \\ Nadezhda M. Krasnova
}

Mari State University, Yoshkar-Ola, Russia

Email: sylne@mail.ru

\section{Doi:10.5901/mjss.2015.v6n3s7p17}

\section{Abstract}

The article deals with symbols and symbolized objects which are used in Mari ritual songs. Mari wedding songs consistently reproduce the main stages and features of the wedding ceremony. The procedure of Mari wedding is strictly fixed and every stage of it expresses a special meaning. The aim of the article is to study a symbol in Mari wedding songs. The surrounding world, the wedding ceremony, its participants and guests, their characteristics, actions and conditions are the main objects of symbolization. The results show that the wedding ceremony in songs is presented as the process of picking up berries, a harvest, road connections, cutting of trees. Unripe berries, a rowan, a poppy, a beautiful, golden bird, a chicken are the symbols of a bride. A groom is associated with a high-spirited horse. Symbols and images of the groom's parents are created by using such characters as a white dove, hatching dove. Some symbols are common in all Finno-Ugric languages. Some unique symbols which appear only in Meadow Mari and Hill Mari wedding songs are described in the article. Some symbols such as a harvest, unripe berries are similar to the symbols of Russian folk songs. The similarity of symbolized objects can be explained by direct contact the Mari have with the Russians. Symbols are the most productive and functionally significant means of expression in Mari wedding songs is a symbol.

Keywords: linguistic folklore, the Mari language, wedding songs, symbol, symbolization.

\section{Introduction}

\subsection{Actualizing the problem}

The first attempt of a systematic analysis of poetics of Mari songs was taken by V.M. Vasilyev. In the preface to the collection of Cheremis songs V.M. Vasilyev considered composition, expressive means, rhythm and rhyme of the Eastern Mari songs (Aptriev, 1908). He mentioned psychological parallelism, emphasized the Tatar influence on the performance of Eastern Mari songs.

Problems of poetics were further studied by V.M. Berdnikov, E.A. Todorovski (1965); they examined issues of the evolution of a long song, poetic means of Mari folk songs, poetry of short songs that are similar to Russian chastooshka (two-line or four-line poem or ditty on some topical or humorous theme) and Tatar tackmacks, short songs. Researchers also described symbolism, metaphor, simile, amplification, sound and rhythmic organization, rhyme in some works devoted to the investigation of poetics of lingering songs. Works by I.S. Ivanov (1998), M.T. Slesareva (1986), I.E. Karpukhin (1982) are devoted to the investigation of expressive means in Mari folk songs.

\subsection{Explore Importance of the Problem}

At present linguists are interested in ceremonial and ritual songs not only due to the need of fixing gradually lost texts, but also the increased attention of the society to traditional culture of the Mari. Besides, each generation tries to pass on to the succeeding one invaluable spiritual heritage of Mari wedding songs.

Despite the transformation and loss of some elements, aspects of the wedding, Mari wedding ceremony continues to function and it maintains its particular and distinguishing features, especially in the rural areas, villages where Mari people try to follow the tradition of their generation. Therefore, it is important to understand the current state of folk texts, their sense, content, aim and function. 


\subsection{Methods and materials}

Descriptive and comparative methods were used while writing the article.

The object of this study is Mari wedding songs which were fixed by the authors of the article from 1987 to 2014 in the Republic of Mari El, Bashkortostan and Tatarstan. Lyrics of Mari songs published in collections of Mari ritual songs were also investigated. The subject of the research is expressive means, symbols used in Mari wedding songs.

\section{Results}

\subsection{Symbols representing the wedding ceremony}

Mari wedding songs represent the whole wedding ceremony and, therefore, all the stages of the wedding are strictly fixed and logical. Symbols are the most productive and functionally significant expressive means in Mari wedding songs.

From Greek 'token', a symbol is assign, whether visual or verbal, which stands for something else within a speech community (Wales, 2001). Symbol is an idea, an image, or an object that has its own content and at the same time it represents in a generalized, non-deployed form a different content. Different symbols are used in our everyday life and, they have a definite purpose. Symbols always serve as the detection of something implicit, unpredictable or not lying on the surface.

Surrounding world, the wedding ceremony, wedding participants and their characteristics, actions, conditions are the subjects of symbolization in Mari wedding songs.

The wedding ceremony itself is presented as the process of picking up berries, a harvest: Мемнанат пасу - кумда пасу: вудена гын, кум турло шурно уна. Кум турло шурным поген налын, туглар-туглаче, пырля илена (Abukaeva, 2009). "Our field is a wide field. If we seed, we will gather a rich harvest. After collecting a rich harvest, let's live together, dear matchmakers". Емышыже кеын, ме погена - кеын шудегече тамже уке. Шочшем ежылдыш, толаш вашкышна: Ме толдегеч, шонышна, ям уке (Abukaeva, 2009). "Berries are ripe and we pick up them. Unripe berries taste awful. Relatives invited us, and we were in a hurry. I think that without us there is no fun." Wedding participants sing these songs at the beginning of the wedding ceremony when the head of a wedding, it is called карm вame in Mari, makes the opening ceremony of the wedding, walks around the table clockwise three times with bread and salt in her hand.

The arrival of the wedding to the home of proxies, where the bride is, revealed in a symbolic situation of gathering clouds: Ола велым пылже толеш, йурде кая, шонет мо, шонет мо? Налаш толшо суан марий налде кая, шонет мо, шонет мо? (Abukaeva, 2009). "Clouds are swooping down. Don't you think it is going to rain? Don't you think that wedding guests will take you with them?" The sentence 'clouds are swooping down' does not talk only about the actual beginning of a rain but also signifies a new chance to begin a new life for a bride and a groom. Different variations of this symbol occur not only in Eastern Mari songs, but also in Hill Mari, Meadow Mari and other Finno-Ugric peoples' songs. Symbolic image of a natural disaster used in the song is very strong and expressive. As above-mentioned song is found in the repertoire of wedding songs of all ethnic groups of Mari, we can assume that it retains peculiar features of the Mari ethnic community. The symbolic situation described in the song is the oldest one.

The symbol of connecting roads as the symbol of family uniting is rather original: Корно денат айста ме каена корныланат корным ушена. Айста-лай шешкылан ме каена, ешланат лай ешым ушена (Abukaeva, 2009). Let's walk along the smooth path. We will connect the roads. Let us go for a bride - and we will unite a family.

Symbolic situation of catching a bird is common in songs of Finno-Ugric peoples and in Russian folk songs. It is widely used in songs of Mari living in Mishkino region of the Republic of Bashkorotstan: Вича-гына воктен чувар чывым теве-теве нангая шем вараш. Капетат сай, тусет чевер - теве шуын тылат пурымаш (Abukaeva, 2009). "A black hawk will catch a colorful chicken in the barn. You are beautiful. It is time to meet your fate." In this song a hen is a symbol which represents a bride. The symbol of a hen is used in Mordva songs, too. Partly this symbol can be explained by Mari wedding ritual of offering a cake decorated with figures of a hen to a bride. In this case, it refers to a bride's wishes to care for her children like a hen. Symbol prefigures a mother.

The idea of future changes coming in a life of a young woman with the groom's arrival to her house is served as the starting point for creation of some interesting symbols. The symbol of tearing bark form a linden serves as a symbol of taking away a bride from her parents' house: Нымыштыжым кушкед налындан - Варажымат кушко шолышда? Ачаже, аваже вигенат улыда - удырдамат кушко шылтышда? "You stripped bastes and where are the poles? Both a father and a mother are here. Where did you hide your daughter? (Abukaeva, 2009). Аркаште тумыжым ме руышна. Пугыланат огыл - таванлан. Тыланет, акай, шешкым кондышна, Уналанат огыл - умырлан (Abukaeva, 2009). "On the hill we cut an oak, not for an arc but for runners. And we brought a daughter-in-law for you, sister. Not as a guest, but 
for the rest of your life." A cut tree is a symbol representing a new house for a bride.

Marriage in Mari wedding songs is associated with bridling a horse: Мемнан имне пеш поро -Той омыта кулылда. Мемнан каче пеш поро - Мотро удыр кулылда (Abukaeva, 2009). "Our good horse needs forged copper collar. Our good fellow needs a beautiful girl." In this song a horse represents male courage, strength and energy. It should be mentioned that the word имне 'horse' is used with the epithet пеш поро 'very kind'. There is no negative meaning of representing marriage in this song.

\subsection{Symbols representing a bride and a groom}

Unripe berries, apple blossoms, a mountain ash, a poppy usually stand for a bride in Mari wedding sons. Symbols of plants embody purity and beauty of a bride: Тугларем, торза ончылныда парчан гына пызле шочылден. Парчан-гына пызле - кече ок воч, шешке, тые ит вожыл - шинча ок воч (Abukaeva, 2009). "Dear matchmaker, in front of your windows a beautiful mountain ash grew, it doesn't let the sun in on us. Dear daughter-in-law do not be shy, we will not put the evil eye on you." The meaning of most of these characters is quite clear, but some of them should be interpreted according to the context. According to the Mari a mountain ash is a plant which provides not only purity, but also safety. It is no accident that Mari put the branches of a mountain ash when they lay vegetables in storage. It is also noteworthy that when the Eastern Maris bury someone they put a sprig of a mountain ash. It is known that a mountain ash is used as means to scare away evil spirits since Ancient Greek times: rowan twigs or leaves of a mountain ash were put into a shepherd's staff. A similar custom was recorded in Scotland, Estonia and Sweden. Even in those places where the rowan tree was called a witch's tree, it was endowed the ability to resist diseases and witchcraft.

Such qualities as purity, whiteness are taken as a basis of assimilation of a bride with pure white clothes: Порт ончолно ош наста киялалеш. Ида рончо - тудо лавырга. Мемнанат шешке умбак ида ончо: вожылалеш тудо - йот наста (Abukaeva, 2009). "There is a white parcel in an outer entrance hall. Do not turn it - it will get dirty. Do not look at our daughter-in-law, she is shy and she is still a stranger." The symbolism of colour dominates in this song. We should mention the fact that the Mari use the epithet ошо 'white' to name themselves. Pagan Mari people call themselves ош мари 'white Mari' which means real Mari. Results show that other colors are not used in Mari wedding songs.

A kind of a compound symbol is the representation of a bride with a beautiful, golden bird in the following song: Эp кынелын туго лектым: изи кайык шортньо шулдыран. Вучалтен киеда, вучыде киеда - шортно гае шешкым кондышна (Abukaeva, 2009). "I got up early in the morning and I went out into the yard and saw a small bird with golden wings. Are you waiting for a bride who is like gold?" A bride is described as an ideal, perfect creation, a symbol of the feeling of affection which a groom as for her.

\subsection{Symbols representing parents}

The image of the father is traditionally created with the help of a symbol кугу mумо 'a mighty, powerful oak': Портончыллай воктенет кугу тумо, Кугу тумо йымалне ош куэ. Ош куэжын парчаже ме улына, Кугу тумо, ачаем, тый улат (Abukaeva, 2009). "There is a powerful oak near the yard. There is a white birch under amighty oak. We are branches of that white birch, and you, my father, is that mighty oak." According to the song, a mighty oak stands for a father. There is another clear symbol in this song, and it is a white birch, which is used to present the image of a mother. This song has personal, cultural associations for the participants of the wedding ceremony.

An oak and a birch have a deep sacred sense in the Mari language. Even at present the Mari continue worshiping them; birch and oak groves serve as a special place of worship for Mari pagans. Currently, there are 649 pagan sacred groves in the Republic of Mar El, but only 347 are taken under state protection. They are considered to be historic monuments of national significance, and at the same time they are the places of pagan worship.

The images of groom's parents are generated in raising or glorifying songs. A white dove is symbolic of parents, a mother and a father. It is explained by the absence of the category of gender in Mari and, that is why, this song can be dedicated to a mother and a father.: Ош портетын шолап йымаланже Ош когорчен игым луктылден. Ош когорчен гае игым куштен, Тачысе кечын калыкым модыктет (Abukaeva, 2009). "Under the eaves of your house a white dove led the chicks. The little ones are hatched. Having raised your children, you, like a white dove, rejoice people."

A symbol of a mother appears in songs very often. Mother's image is the most favourite one in Mari wedding songs. Moreover, a mother is an object of veneration, a symbol of holiness and purity, the embodiment of the ability to unite people, to rally them. A queen bee is a symbol that represents caring, good-hearted, respectful and honorable mother. The Mari are aware of the idea that mother can support and protect in any situation. In our opinion, the significance of this symbol is directly connected with the religious beliefs of Mari people because мукш юмо 'bees' god' is 
represented in the Mari pagan pantheon.

Folk songs represent psychological state of a wedding proxy (a groom's female relative) very accurately and vividly. A bride is taken to proxies' house long before the wedding starts. Earlier, this period could range from three months to three days. So a bride was given the opportunity to meet with her future relatives and neighbors. The meaning and the aim of this ritual is to render the possibility for a newcomer, a bride, to meet future new relatives and neighbours. Currently, taking a bride to proxies' house is a pure formality, and wedding guests do not stay there for a long time. A wedding proxy is responsible for having a bag with presents. There is a belief among Mari people that a proxy will be a real mother for a bride when she lives in worlds beyond her. It should be emphasized that a proxy will have responsibility for a bride and a groom before god and men.

A proxy seems to dote upon a bride; she worries about her future life: Вуешет пидме порсын ялукет ежаргынат, кандын йулалеш. Сыралат гынат, йулет гынат, садак налын каена удырдам (Abukaeva, 2009). "You have put a shawl over your head. It is blue and green. It is burning now. Though you will become angry, you will grieve, anyway, we will take your daughter." In this song a symbol of burning a shawl is the use of a concrete object to represent and abstract idea of proxy's worries about a bride.

An unusual symbol appears in the following song: Портончыл мучаште ший менгешет ит энгерте - когаргет, туглаче. Йулет гынат, когаргет гынат, садак налын каена удырдам (Abukaeva, 2009). "There is a silver pillar in your porch. Do not lean to it - it can burn you. It can burn you. Anyway, we'll take your daughter." This song has a surplus meaning, bright emotional color. A silver pillar symbolizes a proxy who worries about recently born family. Most of the songs, where different symbols appear, are based on parallelism, a device which depends on the repetition of the same structural pattern.

\section{Conclusion}

Thus, a bride, a groom, a proxy, guests of the wedding, wedding ceremony itself are symbolized in the Mari songs. Some symbols such as a harvest, unripe berries are similar with the symbols of Russian folk songs. Generally, the similarity of the symbols can be explained by the socio-cultural, economic contacts of the Mari with the Russians.

Among the symbols, presented in this article, some of them - white clothes, golden birds - are unique to Eastern Mari wedding song. Obviously, songs, where these symbols function, appeared after the collapse of the Mari ethnic unity.

Mari wedding song is the reflection of poetic thinking of people. Simple objects which surround us act as significant and very valuable. Mari people compare one phenomenon with others in wedding songs, reveal common features, and poeticize the world. Symbols, moreover, point to objects and phenomena, which have sacred meaning and convey the emotional state of the participants of the wedding ceremony. Symbols are clear indicators of the identity of Mari mentality.

\section{References}

Abukaeva, L.A. (2009). Wedding songs of Eastern Mari living in Mishkino region. Yoshkar-Ola. Aptriev, A., (1908). Collection of Cheremis songs collected in different regions near Birsk and Sarapul in 1905-1907. Kazan. Berdnikov, V.M., Tudorovskaya E.A. (1965). Poetics of Mari folk songs. Yoshkar-Ola. Ivanov, I.S. (1980). Poetic peculiarities of Mari wedding songs. Journal of Mari Scientific Institute after V.M. Vasilyev, 2, $132-138$.

Ivanov, I.S. (1989). Peculiarities of the system of poetics in Mari wedding songs. Main tendencies of development of Mari folklore and art, 1, 44-49.

Karpukhin, I.E. (1982). Interrelations of Russian and Mari songs in the Republic of Bashkortostan. Folklore of peoples living in Russian Soviet Federative Socialist Republic, 3, 107-115.

Slesareva, M.T. (1986). System of images in Eastern Finno-Ugric peoples' songs, their similarity with epic literature. Problems of ethnic tradition of Udmurt folklore and literature, 1, 17-25.

Wales, K. (2001). A dictionary of stylistics. (2nd ed.). Harlow: Longman. 